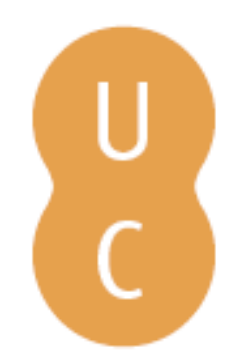

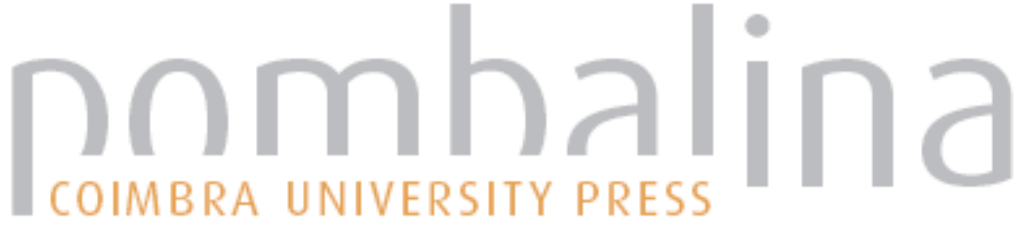

\section{Toward safer firefighting strategies and tactics}

Autor(es): $\quad$ Lahaye, S.; Sharples, J.; Hély, C.; Curt, T.

Publicado por: Imprensa da Universidade de Coimbra

URL

persistente: URI:http://hdl.handle.net/10316.2/44683

DOI: $\quad$ DOI:https://doi.org/10.14195/978-989-26-16-506_166

Accessed : $\quad$ 26-Apr-2023 14:50:20

A navegação consulta e descarregamento dos títulos inseridos nas Bibliotecas Digitais UC Digitalis, UC Pombalina e UC Impactum, pressupõem a aceitação plena e sem reservas dos Termos e Condições de Uso destas Bibliotecas Digitais, disponíveis em https://digitalis.uc.pt/pt-pt/termos.

Conforme exposto nos referidos Termos e Condições de Uso, o descarregamento de títulos de acesso restrito requer uma licença válida de autorização devendo o utilizador aceder ao(s) documento(s) a partir de um endereço de IP da instituição detentora da supramencionada licença.

Ao utilizador é apenas permitido o descarregamento para uso pessoal, pelo que o emprego do(s) título(s) descarregado(s) para outro fim, designadamente comercial, carece de autorização do respetivo autor ou editor da obra.

Na medida em que todas as obras da UC Digitalis se encontram protegidas pelo Código do Direito de Autor e Direitos Conexos e demais legislação aplicável, toda a cópia, parcial ou total, deste documento, nos casos em que é legalmente admitida, deverá conter ou fazer-se acompanhar por este aviso. 


\section{ADVANCES IN}

\section{FOREST FIRE RESEARCH}

\section{8}

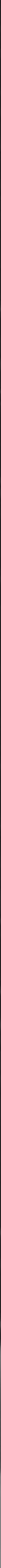


Short contribution - Fire Management

\title{
Toward safer firefighting strategies and tactics
}

\author{
S. Lahaye ${ }^{1,2 *}$; J. Sharples ${ }^{1}$, C. Hély ${ }^{2}$, T. Curt ${ }^{3}$ \\ ${ }^{1}$ School of Physical, Environmental and Mathematical Sciences, University of New South Wales Canberra, \\ ACT 2600, Australia. \{sebastien.lahaye@safecluster.com*\} \\ ${ }^{2}$ Institut des Sciences de l'Evolution de Montpellier (ISEM), EPHE, PSL Research University, CNRS, \\ Université de Montpellier, IRD, Place Eugène Bataillon, CC 065, 34095 Montpellier, France. \\ ${ }^{3}$ Irstea EMAX Mediterranean Ecosystems and Risks, route Cézanne, 13182, Aix-en-Provence cedex 5, \\ France.
}

\begin{abstract}
Adverse weather conditions and fuel accumulation may induce destructive fires. Therefore firefighters are highly exposed to fire entrapments, i.e. to be caught by the fire heat or smoke.

As there are several types of fires, firefighters face different types of mitigation difficulties. They also face different situations potentially leading to entrapment. We suggest here ways to implement safer mitigation practises at both strategical and tactical levels.

We analysed 103 firefighters' entrapments described in both publications and internal reports from fire agencies across Europe, Australasia and North-America. We distinguished three types of fire (i.e. topography-influenced, wind-driven and convective-dominated fires) and we assessed the potential contributions of dynamic fire behaviours in entrapments for each fire type. The dynamic fire behaviours investigated are changes in wind direction, steep slopes prone to flame attachment and leeward slopes prone to vorticity-driven lateral fire spread.
\end{abstract}

Our results show that $94 \%$ of the entrapments in topography-influenced fires have happened on steep slopes prone to flame attachment. We also point out that slopes prone to vorticity-driven lateral fire spread have been the most prominent factor associated with entrapments during wind-driven fires. Finally, in convective-dominated fires, many configurations can lead to entrapments, including those without any obvious dangerous fire behaviour characteristics.

Whereas our study took months to identify risks associated to each fire type, firefighter commanders have to take mitigation strategic decisions within few minutes. On the field, crews have an even shorter decision time to choose safe and efficient tactical options.

This is why dissemination of the fire type concept and consequent safety issues should be declined in several levels and time lags within fire agencies.

At the top level of scientific understanding, fire behaviour analysts should be able to forecast the expected fire type in relation to weather, fuel and topographic inputs. They should both produce maps of dangerous areas, trigger points, key points, and assess the expected efficiency and danger from different strategic options.

Incident commanders, division commanders and other command staff should be aware of the general behaviour of a fire regarding its type. They should also be informed of the associated areas at risk and the most efficient strategies to fight the fire regarding its type.

Finally, crews should be trained to recognise risky zones on the ground and to egress rapidly such zones before dangerous conditions get aligned.

Keywords: entrapment, fire behaviour analyst (FBAN), fire type, flame attachment, vorticity-driven lateral spread (VLS). 


\section{Introduction}

In wide areas of Northern America, Southern Australia or Mediterranean Europe, adverse weather conditions and fuel accumulation may induce very large and destructive fires. Firefighters have developed massive initial attack strategies to protect endangered population and assets as a priority. Therefore, they can become themselves highly exposed to fire entrapments, i.e. to be caught by the fire heat or smoke during their intervention.

The fire type concept (Costa et al. 2011) distinguishes several types of fires, depending on the main driver of the fire propagation, which can be the topography, the wind or the fuel. Therefore firefighters face different types of mitigation difficulties (Lahaye et al. 2014). They also face different risks of entrapment (Page and Butler 2017; Lahaye et al. 2018a).

We investigated more than 100 firefighters' entrapments across the world and we determined both the type of fire and the likely contribution of dynamic fire behaviours. Considering the results, we suggest here ways to implement safer mitigation practises at both strategical and tactical levels.

\section{Fire types and associated risks}

\subsection{Investigation of 103 entrapments}

We analysed 43 firefighters' entrapments in Australia mentioned by Lahaye et al. (2018a) and 48 entrapments in France described by Lahaye et al. (2018b). Most the cases were extracted from fire agencies' unpublished internal reports. We added to this set one entrapment in New Zealand (Pearce et al. 2004), one in Portugal (Viegas et al. 2009), one in Croatia (Viegas et al. 2009), two in Greece (Xanthopoulos 2007) and five in Spain, reported in Viegas et al. (2009), Zamora (2007) and in unpublished reports. Finally, we extended the study to two fully documented cases in the USA: Mann Gulch (Maclean 1992) and South Canyon (Butler et al. 1998). In total, we analysed 103 incidents distributed across three continents (Fig. 1). All of them correspond to fires suddenly exhibiting high rates of spread and intensity.

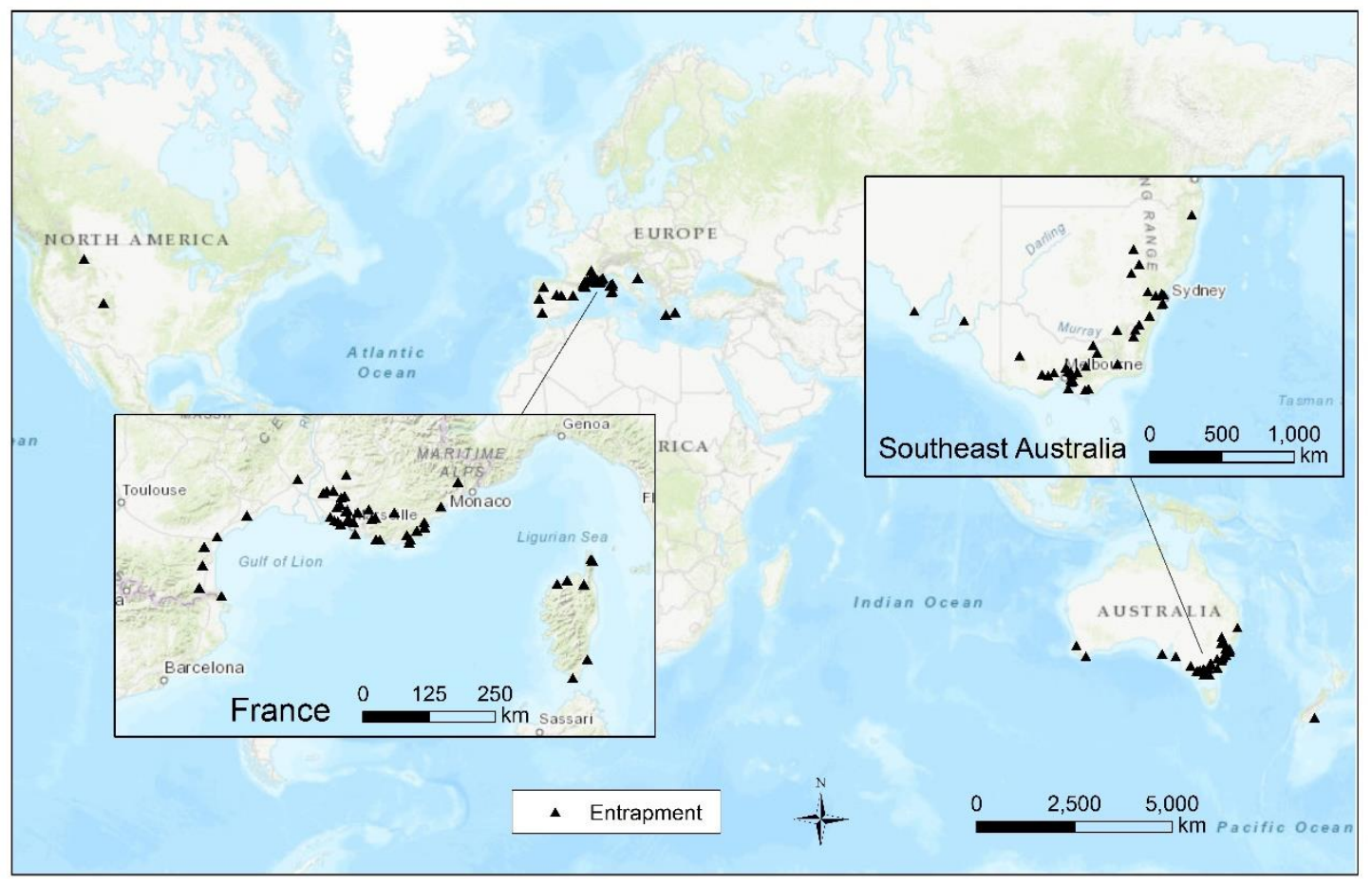

Figure 1 - Location of the entrapments investigated in this study, not representative of the global distribution of incidents. 
Several authors investigated the types of fires (Byram 1959; Rothermel 1991; Morvan 2010) and Costa et al. (2011) proposed a classification of three types: topography-influenced, wind-driven and convective-dominated. Costa et al. (2011) did not provide threshold criteria for these three types of fires but they described their environment and their behaviour so that we could assigned each of the 103 entrapping fires of our set to one of the types.

For each entrapment, we assessed the potential contributions of configurations conducive to dynamic fire, namely changes in wind direction exceeding $45^{\circ}$, upwind slopes steeper than $20^{\circ}$ prone to flame attachment, and leeward slopes prone to vorticity-driven lateral fire spread (VLS) as defined by Sharples et al. (2012). VLS prone landscapes are lee-facing slopes over $20^{\circ}$ with wind speed over $20 \mathrm{~km} \mathrm{~h}^{-1}$ (Simpson et al. 2016). VLS can induce massive spotting likely to propagate the fire over long distances (Fig. 2).

\subsection{Results}

$16 \%$ of the entrapments studied here happened during topography-influenced fires, 55\% during wind-driven fires and $28 \%$ during convective-dominated fires (Table 1).

Table 1 - Distribution of firefighters' entrapments, deaths and injuries regarding the fire types.

\begin{tabular}{lccc}
\hline \multicolumn{1}{c}{ Fire type } & Entrapments & Deaths & Injuries \\
\hline Topography-influenced & 17 & 62 & 29 \\
Wind-driven & 57 & 48 & 71 \\
Convective-dominated & 29 & 34 & 27 \\
\hline
\end{tabular}

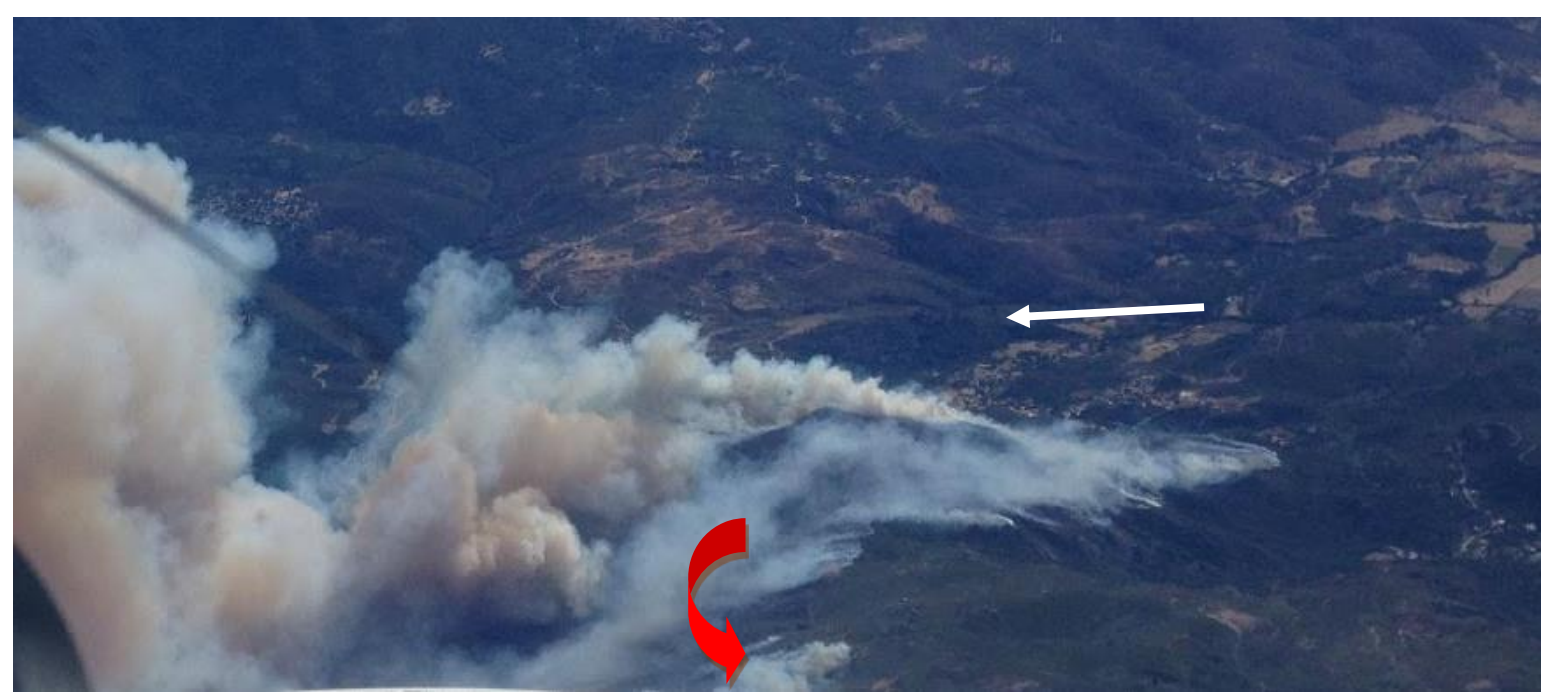

Figure 2 - A case of vorticity-driven lateral spread (VLS) in Corsica, France, 2017. The white arrow figures the main wind direction and the red arrow shows VLS. (Photo: P. Schaller)

Our results show that $94 \%$ of the entrapments in topography-influenced fires occurred on steep slopes prone to flame attachment (Table 2). We also point out that slopes prone to VLS were the most prominent factor associated with entrapments during wind-driven fires. Finally, in convectivedominated fires, many configurations can lead to entrapments, including those without any obvious dangerous or changing fire behaviour characteristics. 
Table 2 - Presence of dynamic fire configurations in entrapments regarding the type of fire. 'None' indicates entrapments where none of the investigated configurations were present.

\begin{tabular}{lcccc}
\hline \multicolumn{1}{c}{ Fire type } & $\begin{array}{c}\text { Wind } \\
\text { shift }\end{array}$ & $\begin{array}{c}\text { Flame } \\
\text { attachment }\end{array}$ & VLS & None \\
\hline Topography-influenced & $29 \%$ & $94 \%$ & 0 & $6 \%$ \\
Wind-driven & $10 \%$ & $32 \%$ & $42 \%$ & $30 \%$ \\
Convective-dominated & $38 \%$ & $24 \%$ & $24 \%$ & $48 \%$ \\
Total & $21 \%$ & $40 \%$ & $30 \%$ & $31 \%$ \\
\hline
\end{tabular}

\section{Discussion}

Whereas this study took months to identify risks associated to each type of fires, firefighter commanders have to take mitigation strategic decisions within few minutes. On the field, crews have an even shorter decision time to choose safe and efficient tactical options. This is why the fire type concept and consequent safety issues should be integrated at different stages of the fire agencies' decision process: before the fires (land management, training, and preparedness), during the fires and after the fires (lessons learned) (Fig.3).

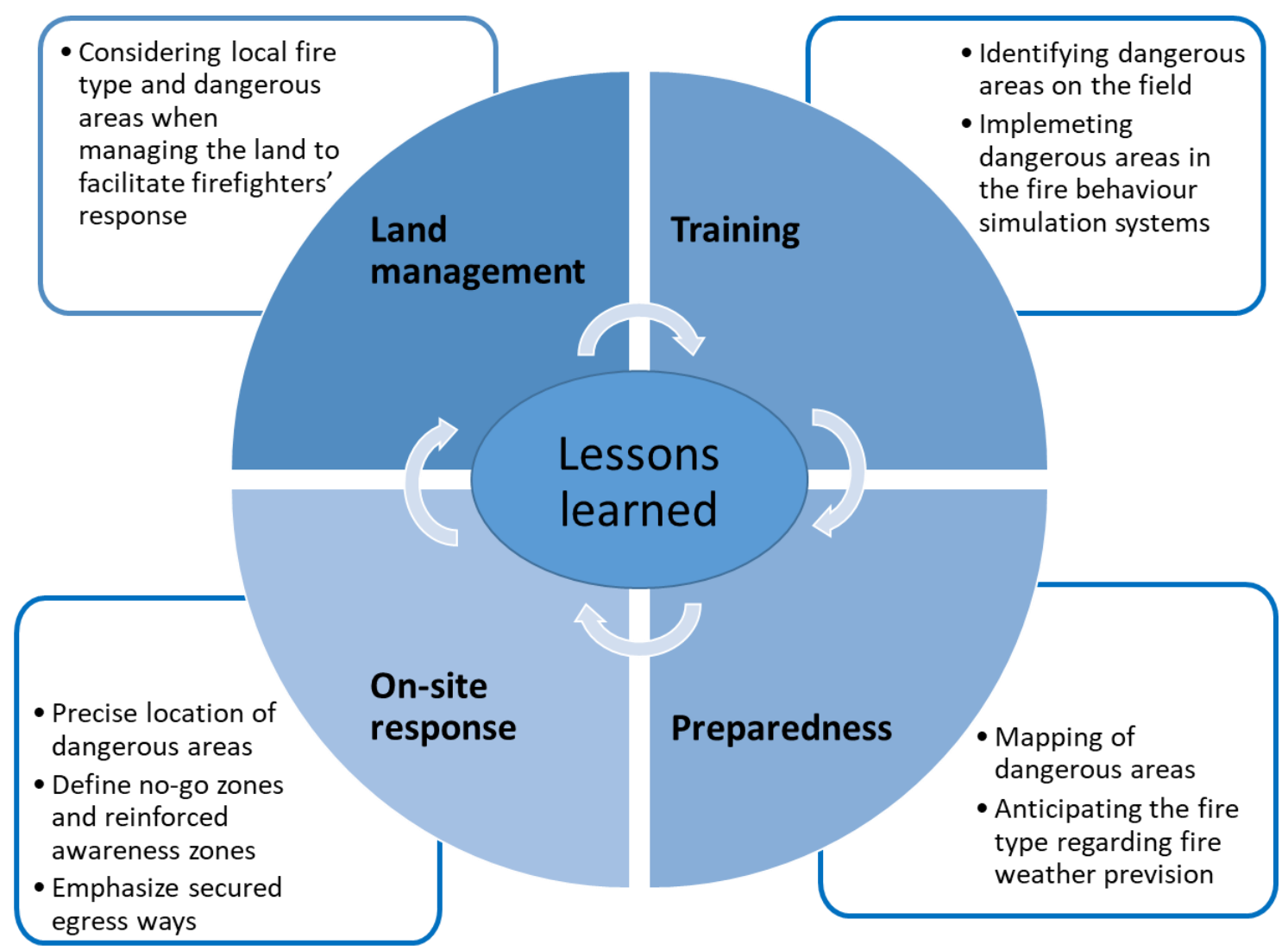

Figure 3 - Concept flow for integrating fire types and safety issues in fire agencies' decision process.

The results of this study should also be disseminated through several levels of decision-making to support the integration in the different activities of the fire agencies.

At the top level of scientific understanding, fire behaviour analysts (FBAN) should be able to forecast the type of fire regarding weather, fuel and topographic inputs. They may also produce maps of dangerous areas, trigger points, key points and assess the expected efficiency and danger of different strategic options. Whereas North American FBAN have developed knowledges and competencies for 
decades (Hardy and Hardy 2007), the situation in Australia and in Europe is more diverse. In Australia, fire agencies in the south-eastern states started to develop FBAN trainings in the late 2000's (Gibos et al. 2014) and then rapidly raised the capability. In Europe, although Molina et al. (2010) identified the key role of FBAN, few agencies have empowered them yet, with the exception of the Catalonian Fire Service (Otero and Nielsen 2017).

Besides of FBAN with strong scientific knowledges and capabilities to predict wind shifts, flame attachment, VLS or other dynamic behaviours, incident commanders, division commanders and other command staff should be aware of the general behaviour of a fire regarding its type. They should also be informed of the associated dangerous areas and the most efficient strategies to fight the fire regarding its type.

Finally, crews should be trained to recognise risky zones on the ground and to egress rapidly such zones before dangerous conditions get aligned. Standard operative procedures acknowledge these dangerous conditions in north America (National Wildfire Coordinating Group 2014) and in Australia (New South Wales Rural Fire Service 2010) but do not differentiate the types of fires. Integrating the types of fires in the procedures may make them more effective. In Europe, especially in France, agencies have focused much on protecting equipment, e.g. trucks and clothing, than on fire behaviour understanding. However, consistent European training systems and facilities may facilitate dissemination of basic procedures to avoid dangerous zones and to egress from them before it is too late.

\section{References}

Butler BW, Bartlette RA, Bradshaw LS, Cohen JD, Andrews PL, Putnam T, Mangan RJ (1998) Fire behavior associated with the 1994 South Canyon Fire on Storm King Mountain, Colorado. USDA Forest Service, Research Paper RMRS-RP-9 (Fort Collins, CO, USA)

Byram GM (1959) Combustion of forest fuels. In 'Forest fire: control and use'.(Ed. KP Davis). pp. 61-89. (New York)

Costa P, Castellnou M, Larranaga A, Miralles M, Kraus D (2011) Prevention of large wildfires using the fire types concept. Generalitat de Catalunya, Fire Paradox European Project (Barcelona, Spain) www.efi.int/files/attachments/publications/handbook-prevention-large-fires_en.pdf.

Gibos K, Slijepcevic A, Wells T, Fogarty L (2014) Building Fire Behavior Analyst (FBAN) Capability and Capacity: Lessons Learned From Victoria, Australia's Bushfire Behavior Predictive Services Strategy. InKeane R, Jolly M, Parson R, Riley K (eds) Missoula, MT, USA. 91. (USDA Forest Service: Missoula, MT, USA)

Hardy CC, Hardy CE (2007) Fire danger rating in the United States of America: an evolution since 1916. International Journal of Wildland Fire 16, 217-231.

Lahaye S, Curt T, Frejaville T, Sharples J, Paradis L, Hely C (2018b) What are the drivers of dangerous fires in Mediterranean France? International Journal of Wildland Fire 27, 155-163. doi:10.1071/WF17087.

Lahaye S, Curt T, Paradis L, Hely C (2014) Classification of large wildfires in South-Eastern France to adapt suppression strategies. InViegas DX (ed) 'Proceedings of 7th International Conference on Forest Fire Research 17-20 Nov 2014', Coimbra, Portugal. 696-708. (ADAI: Coimbra, Portugal) doi:10.4195/978-989-26-0884-6.

Lahaye S, Sharples J, Matthews S, Heemstra S, Price O, Badlan R (2018a) How do weather and terrain contribute to firefighter entrapments in Australia? International Journal of Wildland Fire 27, 8598. doi:10.1071/WF17114.

Maclean N (1992) 'Young men and fire.' (University of Chicago Press: Chicago, USA) https://search.library.wisc.edu/catalog/999694827902121. 
Molina D, Castellnou M, Garcia-Marco D, Salgueiro A (2010) Improving fire management success through fire behaviour specialists. 'Integrated Fire Management - Outcomes of European Project Fire Paradox'. (Eds JS Silva, FC Rego, P Fernandes, E Rigolot) pp. 105-119. (European Forest Institute: Joensuu, Finland)

Morvan D (2010) Physical Phenomena and Length Scales Governing the Behaviour of Wildfires: A Case for Physical Modelling. Fire Technology 47, 437-460.

National Wildfire Coordinating Group (2014) 'Incident Response Pocket Guide.' (National Wildfire Coordinating Group. PMS 461 NFES 1077: Boise, ID, USA)

New South Wales Rural Fire Service (2010) 'Firefighters'pocket book.' (New South Wales Rural Fire Service V.1.3: Sydney, Australia)

Otero I, Nielsen JØ (2017) Coexisting with wildfire? Achievements and challenges for a radical socialecological transformation in Catalonia (Spain). Geoforum 85, 234-246. doi:10.1016/j.geoforum.2017.07.020.

Page WG, Butler BW (2017) An empirically based approach to defining wildland firefighter safety and survival zone separation distances. International Journal of Wildland Fire 26, 655-667. doi:10.1071/WF16213.

Pearce HG, Hamilton RW, Millman RI (2004) Fire behaviour and firefighter safety implications associated with the Bucklands Crossing Fire burnover of 24 March 1998. Forest Research, Rotorua, in association with the New Zealand Fire Service Commission and the National Rural Fire Authority, Forest and Rural Fire Scientific and Technical Series 4. (Wellington, NZ)

Rothermel RC (1991) Predicting behavior and size of crown fires in the northern Rocky Mountains. U.S. Department of Agriculture, Forest Service, Intermountain Research Station. Research Paper INT-RP-438, (Ogden, UT, USA)

Sharples J, McRae RHD, Wilkes SR (2012) Wind-terrain effects on the propagation of wildfires in rugged terrain: fire channelling. International Journal of Wildland Fire 21, 282-296. doi:10.1071/WF10055.

Simpson CC, Sharples JJ, Evans JP (2016) Sensitivity of atypical lateral fire spread to wind and slope. Geophysical Research Letters 43, 1744-1751. doi:10.1002/2015GL067343.

Viegas DX, Simeoni A, Xanthopoulos G, Rossa C, Ribeiro L, Pita L, Stipanicev D, Zinoviev A, Weber R, Dold J, Caballero D (2009) 'Recent Forest Fire Related Accidents in Europe.' (European Commission: Luxembourg) www.forest.jrc.ec.europa.eu/media/cms.../recent-forest-fire-relatedaccidents-in-europe.pdf.

Xanthopoulos G (2007) Forest fire related deaths in Greece: confirming what we already know. In '4th International Wildland Fire Conference 13-17 May 2007, Seville, Spain'. (Seville, Spain). https://www.researchgate.net/publication/242307152_Forest_fire_related_deaths_in_Greece_conf irming_what_we_already_know_1.

Zamora FC (2007) Guía técnica para la investigación de accidentes en la extinción de incendios forestales. Gobierno de Espana, Ministerio de medio ambiente, (Madrid, Spain) http://www.mapama.gob.es/es/desarrollo-rural/temas/politicaforestal/8.Guia_tecnica_para_la_investigaci\%C3\%B3n_de_accidentes_tcm7-336275.pdf. 